\title{
PEMAHAMAN MAHASISWA CALON GURU YANG BERKEMAMPUAN MATEMATIKA TINGGI TERHADAP OPERASI BARIS ELEMENTER (OBE)
}

\author{
Harfin Lanya ${ }^{1}$, Moh. Zayyadi ${ }^{2}$ \\ ${ }^{1,2}$ Program Pendidikan Matematika, Universitas Madura \\ lanya.harfin@gmail.com ${ }^{1}$, zayyadi@unira.ac.id ${ }^{2}$
}

\begin{abstract}
Abstrak
Penelitian ini bertujuan untuk mendeskripsikan pemahaman mahasiswa calon guru yang berkemampuan matematika tinggi terhadap operasi baris elementer. Dalam penelitian ini subjek yang diamati adalah mahasiswa calon guru Universitas Madura semester IV (perempuan) yang berkemampuan matematika tinggi. Peneliti memberikan tes pemahaman dan melakukan wawancara untuk memperoleh data pemahaman subjek terhadap operasi baris elementer. Untuk memperoleh data yang valid, peneliti melakukan triangulasi. Adapun triangulasi yang digunakan adalah triangulasi waktu. Data yang digunakan adalah data yang valid dimana data valid ini dianalisis untuk mendapatkan kesimpulan yang menghasilkan pemahaman mahasiswa calon guru yang berkemampuan matematika tinggi terhadap operasi baris elementer. Mahasiswa calon guru yang berkemampuan matematika tinggi mampu menyatakan definisi operasi baris elementer menggunakan pemahamannya sendiri, menyebutkan operasi yang boleh dilakukan untuk operasi baris elementer, dan menyelesaikan sistem persamaan linear dengan operasi baris elementer.
\end{abstract}

Kata Kunci : Pemahaman, Mahasiswa Calon Guru, Kemampuan Matematika Tinggi, dan Operasi Baris Elementer

\section{Pendahuluan}

Matematika adalah pengetahuan yang sangat penting dalam kehidupan. Disadari atau tidak setiap individu menggunakan matematika dalam menjalankan aktifitasnya. Oleh karena itu, matematika diajarkan mulai dari sekolah dasar sampai perguruan tinggi. Banyaknya konsep matematika yang bersifat abstrak yang harus diserap mahasiswa calon guru dalam waktu yang relatif terbatas menjadikan matematika sebagai matakuliah yang sulit untuk mereka.

Skemp (1987) menyatakan bahwa terdapat dua jenis belajar yang biasa terjadi yaitu habit learning or rotememorizing and learning with understanding. Yang artinya belajar dengan kebiasaan atau belajar dengan hafalan dan belajar dengan pemahaman. Belajar dengan hafalan cendrung akan bersifat sementara karena informasi tersimpan pada memori jangka pendek sedangkan belajar dengan pemahaman berhubungan dengan penyimpanan informasi pada memori jangka panjang. Oleh karena itu, mahasiswa harus belajar dengan pemahaman agar tidak terjadi kesalahan konsep matematika.

Salah satu matakuliah yang diberikan untuk mahasiswa calon guru pada semester IV adalah aljabar linear. Salah satu pokok bahsan pada aljabar linear adalah Operasi Baris Elementer.

Pada matakuliah ini, mahasiswa diajarkan untuk memahami simbol dan memanipulasi simbol. Ovi (2012) mengatakan aljabar dipandang sebagai mata pelajaran yang kaya akan simbol dan manipulasi simbol. Pemahaman mahasiswa terhadap simbol-simbol yang 
tepat sangat membantu dalam mempelajari aljabar.

Sejalan dengan hal diatas, pemahaman mahasiswa terhadap matakuliah aljabar linear pokok bahasan operasi baris elementer berhubungan erat dengan kemampuan matematika. Kemampuan matematika dapat digolongkan menjadi tiga kategori yaitu kemampuan matematika tinggi, kemampuan matematika sedang dan kemampuan matematika rendah. Namun yang akan dipaparkan hanya kemampuan matematika tinggi.

Adapun tujuan dalam penelitian ini adalah untuk mendeskripsikan pemahaman mahasiswa calon guru yang berkemampuan matematika tinggi terhadap operasi baris elementer.

Pemahaman adalah kemampuan menyatakan definisi operasi baris elementer menggunakan bahasanya sendiri, menyebutkan operasi yang boleh dilakukan untuk operasi baris elementer, dan menyelesaikan sistem persamaan linear dengan operasi baris elementer.

Operasi baris elementer adalah operasi yang dilakukan hanya/dengan mengalikan suatu persamaan dengan angka tak nol, menukar dua baris persamaan, dan menambahkan kelipatan dari suatu persamaan untuk persamaan lainnya. (Anton, $2003: 5$ )

Indikator pemahaman mahasiswa calon guru terhadap operasi baris elementer yang digunakan dalam penelitian ini adalah sebagai berikut.

1. Kemampuan menyatakan definisi operasi baris elementer menggunakan bahsanya sendiri

2. Kemampuan menyebutkan operasi yang boleh digunakan pada OBE

3. Kemampuan menyelesaikan SPL dengan OBE.

Dalam penelitian ini, kemampuan mahasiswa dibedakan berdasarkan nilai IPK yang diperoleh untuk semester 1 dan 2. Adapun kategori kemampuan mahasiswa dapat dilihat pada tabel berikut.

Tabel 1. Kriteria Kemampuan Matematika Mahasiswa

\begin{tabular}{|c|c|c|}
\hline Mahasisw & Mahasisw & Mahasisw \\
$\mathbf{a}$ & $\mathbf{a}$ & $\mathbf{a}$ \\
Berkema & Berkema & Berkema \\
mpuan & mpuan & mpuan \\
Matemati & Matemati & Matemati \\
ka Rendah & ka Sedang & ka Tinggi \\
\hline IPK $<$ & $3.00 \leq$ IPK & IPK $\geq 3.5$ \\
3.00 & $\leq 3.5$ & \\
\hline
\end{tabular}

\section{Metode Penelitian}

Penelitian ini digolongkan dalam penelitian deskriptif dengan pendekatan kualitatif karena dalam penelitian ini bertujuan untuk mendeskripsikan pemahaman mahasiswa calon guru yang berkemampuan matematika tinggi terhadap operasi baris elementer yang nantinya menghasilkan data deskriptif berupa kata-kata tertulis atau lisan dari subjek penelitian tentang perilaku yang diamati. Instrumen yang digunakan dalam penelitian ini, meliputi instrumen utama dan instrumen bantu. Instrumen utama adalah peneliti sendiri karena peneliti sebagai pengumpul data dan menginterpretasikan data yang diperoleh selama proses penelitian. Sedangkan instrumen bantu berupa tes kemampuan matematika untuk pemilihan subjek, tes pemahaman terhadap operasi baris elemeter dan pedoman wawancara.

\section{Hasil dan Pembahasan}

Berdasarkan hasil penelitian tentang pemahaman mahasiswa calon guru yang berkemampuan matematika tinggi terhadap operasi baris elementer, diperoleh:

Pemahaman Mahasiswa Calon Guru yang Berkemampuan Tinggi Terhadap Operasi Baris Elementer yaitu:

Mahasiswa calon guru yang berkemampuan matematika tinggi mampu menyatakan definisi operasi baris elementer menggunakan bahasanya 
sendiri. Subjek menyatakan bahwa OBE adalah proses manipulasi simbol yang aturannya adalah menggunakan 3 operasi yaitu perkalian baris dengan angka tak nol, pertukaran baris, dan menambahkan kelipatan dari suatu persamaan kepada persamaan lainnya.

Mahasiswa calon guru yang berkemampuan matematika tinggi mampu menyebutkan operasi yang boleh digunakan pada OBE yaitu pertukaran baris, perkalian baris dengan angka tak nol dan menambahkan suatu baris dengan kelipatan baris lainnya.

Mahasiswa calon guru yang berkemampuan matematika tinggi mampu menyelesaikan Sistem Persamaan Linear dengan Operasi Baris Elementer.

\section{Simpulan}

Pemahaman Mahasiswa Calon Guru yang Berkemampuan Matematika Tinggi Terhadap OBE

\section{Daftar Rujukan}

Anton, Howard. 2003. Aljabar Linear Elementer Edisi Kelima. Jakarta : Erlangga.

Ovi. 2012. Pemahaman Siswa SMP Terhadap Simbol Sama Dengan dan Relasi Ekuivalensi Dalam Menyelesaikan Persamaan Matematika Ditinjau Dari
Mahasiswa calon guru yang berkemampuan matematika tinggi mampu menyatakan definisi operasi baris elementer menggunakan bahasanya sendiri. Subjek menyatakan bahwa OBE adalah proses manipulasi simbol yang aturannya adalah menggunakan 3 operasi yaitu perkalian baris dengan angka tak nol, pertukaran baris, dan menambahkan kelipatan dari suatu persamaan kepada persamaan lainnya.

Mahasiswa calon guru yang berkemampuan matematika tinggi mampu menyebutkan operasi yang boleh digunakan pada OBE yaitu pertukaran baris, perkalian baris dengan angka tak nol dan menambahkan suatu baris dengan kelipatan baris lainnya.

Mahasiswa calon guru yang berkemampuan matematika tinggi mampu menyelesaikan Sistem Persamaan Linear dengan Operasi Baris Elementer.

Kemampuan Matematika. Tesis. Universitas Negeri Surabaya. (Tidak Dipublikasikan)

Skemp, Richard R. (1987). The psycology of learning mathematics. New York : Penguin Books Ltd.

Sugiono. (2010). Memahami penelitian kualitatif. Bandung: CV. Alfabeta 
Harfin Lanya ${ }^{1}$, Moh. Zayyadi ${ }^{2}$ : Pemahaman Masalah Calon Guru yang Berkemampuan Matematika Tinggi terhadap Operasi Baris Elementer (OBE)

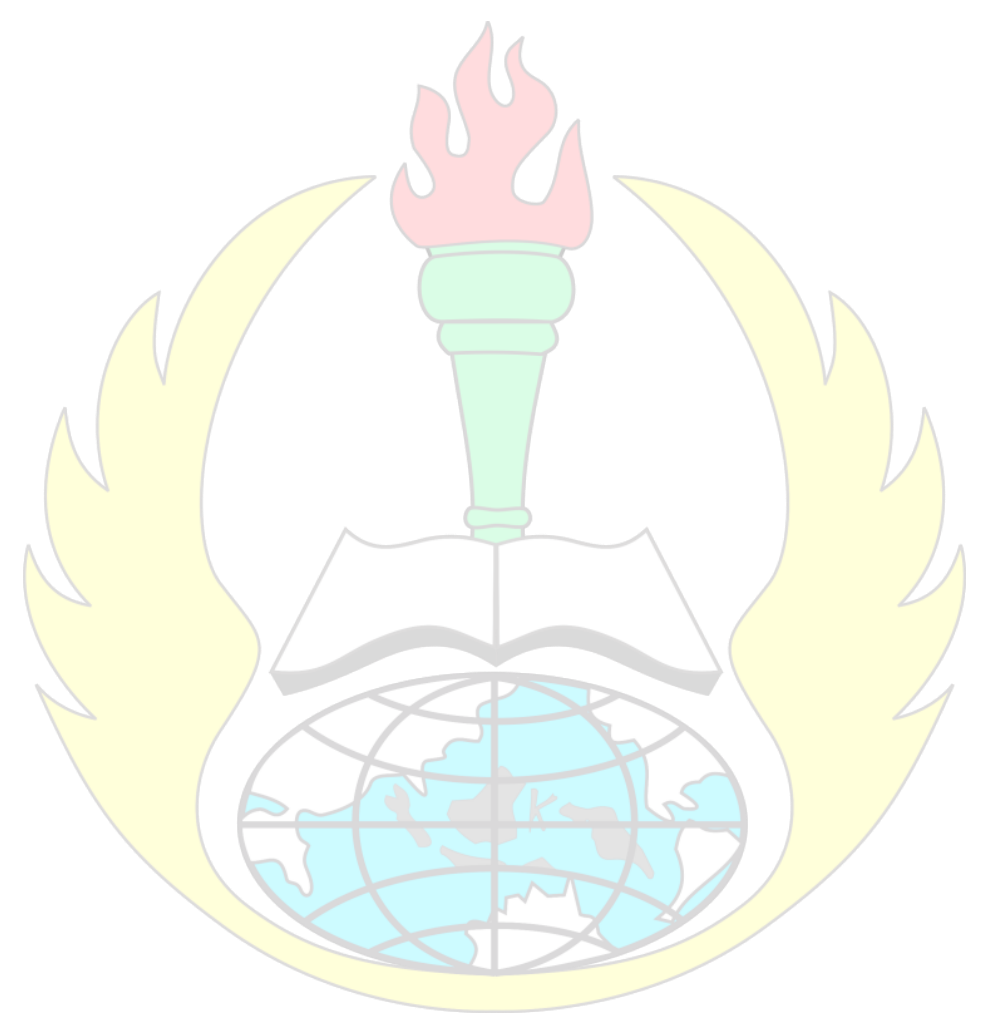

